\title{
Modeling, dialogue, and globality: Biosemiotics and semiotics of self. 1. Semiosis, modeling, and dialogism
}

\author{
Augusto Ponzio \\ Dept. of Linguistics and Text Analysis, University of Bari \\ Via Garruba 6, 70100 Bari, Italy \\ e-mail: ponzio@mlx.pandora.it
}

\begin{abstract}
With our paper we intend to offer a critical overview of state of the art in semiotics, with specific reference to theoretical problems concerning the relationship between culture and nature. In other words, we intend to focus on the relationship between the concepts of semiosphere (Lotman) and biosphere (Vernadsky) considering the various approaches to this issue and proposing our own point of view. An important reference for a valid overview view of semiotics today is the Handbook Semiotik/Semiotics. It is no incident that the subtitle of this work is A Handbook on the Sign-Theoretic Foundations of Nature and Culture. In this handbook a fundamental role is carried out by Thomas A. Sebeok and his particular approach to semiotics, which may be designated as 'global semiotics'. One of the pivotal concepts in Sebeok's global semiotics is that of modeling which traverses nature and culture. This concept connects natural semiosis and cultural semiosis and ensues in an original formulation of the relationship between the notions of 'semiosphere' and 'biosphere'. Such problematics respond to semiotic research in Tartu today, especially as it finds expression in the present journal. And, in fact, as in his book of 2001, Global Semiotics, Sebeok often underlined the importance of the Estonian connection himself in his writings for the development of semiotics.
\end{abstract}

\section{From global semiotics onwards}

This paper proposes a critical overview of semiotics today. For a description and analysis of the state of the art an important point of reference is Semiotik/Semiotics. A Handbook on the Sign-Theoretic Foundations of Nature and Culture, edited by Roland Posner, Klaus 
Robering, Thomas A. Sebeok, 1997-2003. This work includes four volumes (the fourth is forthcoming) of more than 3000 pages with 178 articles written by 175 authors from 25 countries. As such it may be considered as a representation of the general state of research in descriptive and applied semiotics compared with other single disciplines and interdisciplinary approaches including medicine, physics, chemistry, biology, psychology, sociology, economics, mathematics, logic, grammar, stylistics, poetics, musicology, aesthetics, philosophy, etc.

This handbook studies sign processes in human cultures as well in non-human animals, in their orientation, perception and communication activities, in the metabolism of all living organisms generally, therefore in the behaviour of all living beings. In relation to human culture it deals with social institutions, everyday human communication, information processing in machines, knowledge and scientific research, the production and interpretation of works in literature, music, art and so forth.

Semiotics owes to Sebeok its current configuration as 'global semiotics'. By virtue of this 'global' or 'holistic' approach, Sebeok's research into the 'life of signs' may immediately be associated with his concern for the 'signs of life'. In his view, semiosis and life coincide (however, for a critical discussion of 'the relationships between the concepts of life process and sign process', arguing against what he considers the danger of oversimplifying equations, see Kull 2002). Semiosis originates with the first stirrings of life, which leads to his formulation of an axiom he believes cardinal to semiotics: 'semiosis is the criterial attribute of life'. Semiotics provides a point of convergence and observation post for studies on the life of signs and the signs of life. Moreover, Sebeok's global approach to sign life presupposes his critique of anthropocentric and glottocentric semiotic theory and practice. In his explorations of the boundaries and margins of the science or (as he also calls it) 'doctrine' of signs he opens the field to include zoosemiotics (a term he introduced in 1963) or even more broadly biosemiotics, on the one hand, and endosemiotics, on the other (see Sebeok, 'Biosemiotics. Its roots, proliferations, and prospects', in Sebeok 2001: 31-43). In Sebeok's conception, the sign science is not only the 'science qui étude la vie des signes au sein de la vie sociale' (Saussure), that is, the study of communication in culture, but also the study of communicative behaviour in a biosemiotic perspective. 
The object of global semiotics, of semiotics of life, is the semiosphere. This term is taken from Juri M. Lotman (1990) but is understood by Sebeok ('Global semiotics', ${ }^{1}$ Sebeok 2001: 1-16) in a far more extended sense than Lotman's. In fact, the latter limited the sphere of reference of the term 'semiosphere' to human culture and claimed that outside the semiosphere thus understood, there is no communication (cf. Lotman 1990: 123-124). On the contrary, in the perspective of global semiotics where semiosis coincides with life (in this sense we may also call it 'semiotics of life'), the semiosphere identifies with the biosphere, term coined in Russian by Vladimir Vernadskij in 1926, and emerges therefore as the semiobiosphere. Global semiotics is in a position to evidence the extension and consistency of the sign network which obviously includes the semiosphere in Lotman's sense as constructed by human beings, by human culture, signs, symbols and artifacts, etc. But global semiotics underlines the fact that the semiosphere is part of a far broader semiosphere, the semiobiosphere, a sign network human beings have never left, and to the extent that they are living beings, never will.

\section{Another meaning of 'semiotics'}

We may add another meaning of 'semiotics' in addition to the general science of signs: that is, as indicating the specificity of human semiosis. Sebeok elaborates this concept in a text of 1989 'Semiosis and semiotics: what lies in their future?', now Chapter 9 of his book $A$ Sign is Just a Sign (1991: 97-99). We consider it of crucial importance for a transcendental founding of semiotics given that it explains how semiotics as a science and metascience is possible. Says Sebeok:

Semiotics is an exclusively human style of inquiry, consisting of the contemplation - whether informally or in formalized fashion - of semiosis. This search will, it is safe to predict, continue at least as long as our genus survives, much as it has existed, for about three million years, in the successive expressions of Homo, variously labeled - reflecting, among other attributes, a growth in brain capacity with concomitant cognitive abilities -

Global Semiotics. Plenary lecture delivered on June 18,1994 as Honorary President of the Fifth Congress of the International Association for Semiotic Studies, held at the University of California, Berkeley. Published in Sebeok 2001: $1-16$. 
habilis, erectus, sapiens, neanderthalensis, and now s. sapiens. Semiotics, in other words, simply points to the universal propensity of the human mind for reverie focused specularly inward upon its own long-term cognitive strategy and daily maneuverings. Locke designated this quest as a search for 'humane understanding'; Peirce, as 'the play of musement'. (Sebeok 1991: 97)

This meaning of semiotics is implicitly connected with the general plan of Semiotik/Semiotics and its typology of semiosis.

In the world of life, which coincides with semiosis (see Sebeok 1997: 436-437), human semiosis is characterized as metasemiosis, that is, as the possibility of reflecting on signs. This means to make signs not only the object of interpretation not distinguishable from the immediate response to these signs, but also of interpretation understood as reflection on signs, as the suspension of response and possibility of deliberation. We may call this specific human capacity for metasemiosis 'semiotics'. Developing Aristotle's correct observation, made at the beginning of his Metaphysics, that man tends by nature to knowledge, we could say that man tends by nature to semiotics (see Petrilli 1998).

Human semiosis or anthroposemiosis is characterized as semiotics.

\section{Substitution and interpretation}

Semiosis is an event in which something functions as a sign. We find the standard notion of semiotics in Article 1, 'Semiotics and its presentation', of Semiotik/Semiotics:

We therefore stipulate that the following is a necessary and sufficient condition for something to be a semiosis: $A$ interprets $B$ as representing $C$. In this relational characterization of semiosis, $A$ is the interpreter, $B$ is some object, property, relation, event, or state of affairs, and $C$ is the meaning that $A$ assigns to $B$. (Posner 1997a: 4)

In a Peircean definition, $A$ is viewed as the Interpretant that some interpreter uses to relate $B$, the Representamen, to $C$, the Object.

According to Sebeok (1994: 10-14), the Object $(O)$ as well as the Interpretant $(I)$ are Signs. Consequently, we may rewrite $O$ as $S_{O_{n}}$ and $I$ as $S_{I n}$, so that both the first distinction and the second are resolved in two sorts of signs. 
In our opinion, the sign is firstly an interpretant (cf. Petrilli 1998: 3-4) in accordance with Peirce who reformulated the classic notion of substitution, in the medieval expression above, in terms of interpretation.

In fact, the Peircean terms of the sign include what we may call the interpreted sign, on the side of the object, and the interpretant, in a relation where the interpretant is what makes the interpreted sign possible. The interpreted becomes a sign component because it receives an interpretation. But the interpretant in turn is also a sign component with a potential for engendering a new sign. Therefore, where there is a sign, there are immediately two, and given that the interpretant can engender a new sign, there are immediately three, and so forth as conceived by Peirce with his notion of infinite semiosis, which describes semiosis as a chain of deferrals from one interpretant to another.

To analyze the sign beginning from the object of interpretation, that is, the interpreted, means to begin from a secondary level. In other words, to begin from the object-interpreted means to begin from a point in the chain of deferrals, or semiosic chain, which cannot be considered as the starting point. Nor can the interpreted be privileged by way of abstraction at a theoretical level to explain the workings of sign processes. An example: a spot on the skin is a sign insofar as it may be interpreted as a symptom of sickness of the liver: this is already a secondary level in the interpretive process. At a primary level, retrospectively, the skin disorder is an interpretation enacted by the organism itself in relation to an anomaly which is disturbing it and to which it responds. The skin disorder is already in itself an interpretant response.

To say that the sign in the first place is an interpretant means that the sign is firstly a response. We could also say that the sign is a reaction: but only on the condition that by 'reaction' we understand 'interpretation' (similarly to Morris's behaviourism, but differently from the mechanistic approach). To avoid superficial associations with the approaches they respectively recall, the expression 'solicitationresponse' is preferable with respect to the expression 'stimulusreaction'. Even a 'direct' response to a stimulus, or better solicitation, is never direct but 'mediated' by an interpretation. Unless it is a 'reflex action', the formulation of a response involves identifying the solicitation, situating it in a context, and relating it to given behavioural parameters (whether a question of simple types of beha- 
viour, e.g., the prey-predator model, or more complex behaviours connected with cultural values, as in the human world).

The sign is firstly an interpretant, a response through which, on the one hand, something else is considered as a sign and becomes its interpreted, and which, on the other, may engender an infinite chain of signs.

In sum, in Peirce's view, semiosis is a triadic process and relation whose components include sign (or representamen), object and interpretant. 'A Sign, or Representamen, is a First which stands in such a genuine triadic relation to a Second, called its Object, as to be capable of determining a Third, called its Interpretant, to assume the same triadic relation to its Object in which it stands itself to the same Object' ( $C P$ 2.274). Therefore, the sign stands for something, its object 'not in all respects, but in reference to a sort of idea' $(C P$ 2.228). However, a sign can only do this if it determines the interpretant which is 'mediately determined by that object' ( $C P$ 8.343): semiosis is action of sign and action on sign, activity and passivity. 'A sign mediates between the interpretant sign and its object' insofar as it refers to its object under a certain respect or idea, the ground, and determines the interpretant 'in such a way as to bring the interpretant into a relation to the object, corresponding to its own relation to the object' (CP 8.332).

Thanks to what we call 'semiotic materiality', the interpreted object has its own consistency, a capacity to resist just any interpretation, which the interpretant will have to take into account and adjust to. What is interpreted and becomes a sign because of this - whether it be an utterance or a whole line of conduct (verbal and nonverbal), or a written text, or a dream, or a somatic symptom - does not lie at the mercy of a single interpretant. This is so because the interpreted is open to several interpretations and is therefore the place where numerous interpretive routes intersect.

Semiotics must reflect upon the conditions of possibility of what Husserl calls the already given, already done, already constituted, already determined world. And this is necessary to critical analysis of the world's current configuration, with a view to alternative planning. We might say that semiotics carries out the overall task of what Husserl calls constitutive phenomenology. As he shows in particular in Erfahrung und Urteil [Experience and judgement], 1948, the aim of constitutive phenomenology is to clarify the entire complex of operations leading to the constitution of a possible world. To investigate 
how the world is formed means to deal with the essential form of the world in general and not our real effectively existent world. This means to investigate the modeling structures and processes of the human world not simply in terms of factuality, reality and history but also in terms of potential and possibility. Such an investigation is specific also in the sense that it deals with a species-specific modality of constructing the world. In fact, unlike other animals, the human animal is characterized by its capacity for constructing innumerable possible worlds. With Sebeok we call the human modeling device of the world 'language'. Such a capacity exists uniquely in the human species, because unlike all other species only humans are able to construct innumerable real or imaginary, concrete or fantastic worlds and not just a single world (cf. Sebeok 1991).

\section{Semiosis and dialogism}

The interpretant of a sign is another sign which the first creates in the interpreter, 'an equivalent sign, or perhaps a more developed sign' (CP 2.228). Therefore the interpretant sign cannot be identical to the interpreted sign; it cannot be a repetition, precisely because it is mediated, interpretive and therefore always new. With respect to the first sign, the interpretant is a response, and as such it inaugurates a new sign process, a new semiosis. In this sense it is a more developed sign. As a sign the interpretant determines another sign which acts, in turn, as an interpretant: therefore, the interpretant opens to new semioses, it develops the sign process, it is a new sign occurrence. Indeed, we may state that every time there is a sign occurrence, including the 'First Sign', we have a 'Third', something that is mediated, a response, an interpretive novelty, an interpretant. This confirms our statement that a sign is constitutively an interpretant. The fact that the interpretant (Third) is in turn a sign (First), and that the sign (First) is in turn an interpretant (is already a Third) contextualizes the sign in an open network of interpretants according to the Peircean principle of infinite semiosis or endless series of interpretants (cf. $C P$ 1.339).

Therefore, the meaning of a sign is a response, an interpretant that calls for another response, another interpretant. This implies the dialogic nature of sign and semiosis. A sign has its meaning in another sign which responds to it and which in turn is a sign if there is 
another sign to respond to it and interpret it, and so forth ad infinitum. In our terminology (Ponzio 1985; 1990b; Ponzio et al. 1999) the 'First Sign' in the triadic relation of semiosis, the object that receives meaning, is the interpreted, and what confers meaning is the interpretant which may be of two main types.

The interpretant which enables recognition of the sign is an interpretant of identification, it is connected with the signal, code and sign system. The specific interpretant of a sign, that which interprets the actual sense, is the interpretant of answering comprehension. This second type of interpretant does not limit itself to identifying the interpreted, but rather expresses its properly pragmatic meaning, installing with it a relation of involvement and participation: the interpretant responds to the interpreted and takes a stand towards it.

This bifocal conception of the interpretant is in line with Peirce's semiotics, which is inseparable from his pragmatism. In a letter of 1904 to Victoria Welby, Peirce wrote that if we take a sign in a broad sense, its interpretant is not necessarily a sign, but an action or experience, or even just a feeling (cf. $C P$ 8.332). Here, on considering the interpretant as not being necessarily a sign, Peirce is using the term 'sign' in a strict sense. In fact the interpretant understood as a response that signifies, that renders something significant and that consequently becomes a sign cannot be anything else but a sign occurrence, a semiosic act, even when a question of an action or feeling. In any case, we are dealing with what we are calling an 'interpretant of answering comprehension', and therefore a sign.

\section{Semiosis as a prerogative of organisms}

In his article 'The evolution of semiosis', Sebeok (1997: 436) discusses the question 'what is semiosis?' citing Morris (1946: 253), who defined semiosis as 'a process in which something is a sign to some organism'. This definition implies effectively and ineluctably, says Sebeok, that in semiosic processes there must be a living entity, which means that there could not have been semiosis prior to the evolution of life.

For this reason one must, for example, assume that the report, in the King James version of the Bible (Genesis I: 3), quoting God as having said 'Let there be light,' must be a misrepresentation; what God probably said was 'let 
there be photons,' because the sensation of perception of electromagnetic radiation in the form of optical signals, that is, luminance, requires a living interpreter, and the animation of matter did not come to pass much earlier than about 3,900 million years ago. (Sebeok 1997: 436)

Let us return to Morris's definition. 'Signs', says Morris, 'are therefore described and differentiated in terms of the dispositions to behaviour which they cause in their interpreters' (Morris 1971: 75).

\section{Semiosis as biosemiosis}

In 'The evolution of semiosis' Sebeok discusses the question of the cosmos before semiosis and after the beginning of the Universe with reference to the regnant paradigm of modern cosmology, that is the Big Bang theory. Before the appearance of life on our planet - the first traces of which date back to the so-called Archaean Aeon, from 3,900 to 2,500 million years ago - there were only physical phenomena involving interactions of nonbiological atoms and, later, of inorganic molecules. Such interactions may be described as 'quasisemiotic'. But the notion of quasi-semiosis must be distinguished from that of 'protosemiosis' as understood by the Italian oncologist Giorgio Prodi (1977) (to whom is dedicated as a 'bold trailblazer of contemporary biosemiotics' the milestone volume Biosemiotics, edited by Sebeok and Umiker-Sebeok 1992). In fact, in the case of physical phenomena the notion of 'protosemiosis' is only a metaphorical expression. In Sebeok's view, to semiosis must be assigned that which concerns life. He distinguishes nonbiological interactions from 'primitive communication', which refers to transfer of informationcontaining endoparticles, such as exists in neuron assemblies where such transfer is managed in modern cells by protein particles.

Since there is not a single example of life outside our terrestrial biosphere, the question of whether there is life/semiosis elsewhere in our galaxy, let alone in deep space, is wide open. Therefore - says Sebeok - one cannot but hold 'exobiology semiotics' and 'extraterrestrial semiotics' to be twin sciences that so far remain without a subject matter (cf. Sebeok 1997: 437).

In the light of present-day information, all this implies that at least one link in the semiosic loop must necessarily be a living and terrestrial entity, which may simply be a portion of an organism, or 
even an artifactual extension fabricated by a human being. Semiosis is after all terrestrial biosemiosis. A pivotal concept in Sebeok's research as well as in the Semiotik/Semiotics handbook is the identification of semiosis and life. On one hand semiosis is considered as the criterial feature that distinguishes the animate from the inanimate, on the other, sign processes have not always existed in the course of the development of the universe: sign processes and the animate originated together with the development of life. Identification of semiosis and life invests biosemiotics with a completely different role from that conceived by Umberto Eco (1975) when he refers to 'the inferior threshold of semiotics', or from it's more reductive interpretation as a sector of semiotics which in his view is a cultural science. In Sebeok's research semiotics is interpreted and practiced as a life science, as biosemiotics.

This conception of semiosis as biosemiosis is the object of Article 19, 'Biosemiose' ['Biosemiosis'] by Thure von Uexküll in $S / S$ (T. v. Uexküll 1997; see also T. v. Uexküll 1992; Sebeok et al. 1999). In this article, Th. von Uexküll distinguishes between three different kinds of semiosis characterized by differences in the roles of emitter and receiver. Th. von Uexküll calls these three kinds of semiosis:

(1) semiosis of information or signification;

(2) semiosis of symptomatization;

(3) semiosis of communication.

In semiosis of information or signification we have an inanimate environment which acts as a 'quasi-emitter' without a semiotic function. The receiver, i.e., a living entity, a living system, which makes whatever it receives meaningful via its receptors, must perform all semiotic functions. In semiosis of symptomatization the emitter is a living being sending out signals through its behaviour or posture which are not directed towards a receiver and do not await an answer. The receiver receives signals as signs called 'symptoms'. In semiosis of communication signs are emitted for the receiver and must find the meaning intended by the emitter (cf. T. v. Uexküll 1997: 449-450).

\section{Reformulating Thure von Uexküll's typology of semiosis}

In our terminology and in accordance with Peirce, these three kinds of semiosis, which are characterized by differences in the role played by emitter and receiver, may be reformulated in terms of differences in 
the roles of the interpretant sign and the interpreted sign. We can say that

(1) the interpreted may become a sign only because it receives an interpretation from the interpretant, which is a response (semiosis of information); or

(2) before its interpretation as a sign by the interpretant, the interpreted is itself an interpretant response (symptom) which however is not oriented to being interpreted as a sign (semiosis of symptomatization);

(3) before its interpretation as a sign by the interpretant, the interpreted is itself an interpretant response which is now directed at being interpreted as a sign, i.e., it calls for another interpretant response (semiosis of communication). Our reformulation of Th. von Uexküll's typology of semiosis, distinguished by differences in participation in interpretation by the interpreted and interpretant, presents some advantages over the conception of semiosic differences established on the basis of 'emitter' and 'receiver' participation. We believe that our reformulation:

(a) emphasizes the role of the interpretant in semiosis;

(b) explains the meaning of 'the inanimate quasi-interpreter' in semiosis of information or signification as the 'interpreted-non-interpretant' (while in semiosis of symptomatization the interpreted is an interpretant-interpreted which is not directed at being interpreted as a sign; and in semiosis of communication the interpreted is an interpreted-interpretant directed at being interpreted as a sign);

(c) identifies semiosis with the capacity for interpretation, i.e., for response;

(d) confirms the importance of the pragmatic dimension in semiosis;

(e) is in line with Th. von Uexküll's definition of biosemiotics as 'interpretation of interpretation', or, in a word, 'metainterpretation'. Semiosis of information or signification, semiosis of symptomatization, and semiosis of communication are founded in a specific type of modeling characteristic of a specific life form. The capacity of a species for modeling is required as an a priori for processing and interpreting perceptual input in its own way.

Thus we may say with Sebeok:

As Peirce ( $C P$ 1.358) taught us, 'every thought is a sign', but as he also wrote (CP 5.551), 'Not only is thought in the organic world, but it develops there.' 
Every mental model is, of course, also a sign; and not only is modeling an indispensable characteristic of the human world, but also it permeates the entire organic world, where, indeed, it developed. The animals' milieu extérieur and milieu intérieur, as well as the feedback links between them are created and sustained by such models. A model in this general sense is a semiotic production with carefully stated assumptions and rules for biological operations. (Sebeok 1991: 57)

\section{Centrality of the interpretant in semiosic processes}

Thure von Uexküll's model is so broad as to include sign processes from microsemiosis and endosemiosis to semiosis of higher organisms through to human biosemiotic metainterpretation. This model covers most of the complete catalogue of elements postulated for semiosis in Article 5, 'Model of semiosis', by Martin Krampen (1997).

Krampen's semiosic matrix is centered on the notion of interpretant. In fact, as we have already stated, the interpretant mediates between solicitation (interpretandum) and response (signaling behaviour or instrumental behaviour). In Peirce's view such mediation is what distinguishes a semiosis from a mere dynamical action — 'or action of brute force' - which takes place between the terms forming a pair. On the contrary, semiosis results from a triadic relation. It 'is an action, or influence, which is, or involves, a cooperation of three subjects, such as a sign, its object, and its interpretant', nor is it 'in any way resolvable into action between pairs' (CP 5.484). The interpretant does not occur in physical phenomena or in nonbiological interactions, in short, in the inorganic world. As a consequence, Morris defines semiosis as 'a process in which something is a sign to some organism' (Morris 1971: 336). This definition according to our previous statements must not only be interpreted restrictively as referring to a whole organism, but also in a wider sense as referring to any living being or living system whatever.

In the article 'Models of semiosis' the semiosic matrix is also used to discuss the various types of semioses postulated in the history of semiotics. Consequently, the famous 'functional cycle' described by Jakob von Uexküll (1982) - this 'pivotal model', this 'simple albeit not linear, diagram', which 'constitutes a cybernetic theory of modeling so fundamental that the evolution of language cannot be grasped without it' (Sebeok 1994: 122) - may be represented within the semiosic matrix. 


\section{The dialogic nature of signs}

Dialogue too is illustrated graphically through the semiosic matrix (cf. Krampen 1997: 260). The author of the article in question maintains that dialogue commences with signaling behaviour from a sender that intends to communicate something about an object. What is not taken into account is that the 'if ... then' inference, hypothesis formation, and 'chain of thought' are dialogic forms in themselves. Contrary to Krampen's view, for the 'if ... then' model or 'chain of thought' to have a dialogue form, it is not necessary that the 'if ... then' model should 'combine with the dialogue model' as when 'the semiosis of the former type triggers a signaling behaviour', nor that the 'chain of thought' should 'occur in the organisms of the participants' (Krampen 1997: 260).

In inference, in the hypothetical argument, and in the chain of interpreted and interpretant thought signs generally, dialogue is implied in the relation itself between the interpreted sign and the interpretant sign (cf. Ponzio 1985; 1990a; 1997b; Ponzio et al. 1999). The degree of dialogism is minimal in deduction, where the relation between the premises and the conclusion is indexical: here, once the premises are accepted the conclusion is obligatory. In induction, which too is characterized by a unilinear inferential process, the conclusion is determined by habit and is of the symbolic type: identity and repetition dominate, though the relation between the premises and the conclusion is no longer obligatory. By contrast, in abduction the relation between premises and conclusion is iconic and is dialogic in a substantial sense, in other words, it is characterized by high degrees of dialogism and inventiveness as well as by a high-risk margin for error. To claim that abductive argumentative procedures are risky is to say that they are mostly tentative and hypothetical with only a minimal margin for convention (symbolicity) and mechanical necessity (indexicality). Therefore, abductive inferential processes engender sign processes at the highest levels of otherness and dialogism. Thus we may say that 'abductive reasoning' (see the excellent entry by Wirth 1998 ) is at once 'dialogic reasoning'.

In Semiotik/Semiotics a direct analysis of the concept of dialogism is lacking, and yet semiosis as evidenced in this handbook is a dialogic process. The relation between sign (interpreted) and interpretant, as understood by Peirce, is a dialogic relation. We have already evidenced the dialogic nature of sign and semiosis. In 
semiosis of information or signification (T. v. Uexküll 1997), where an inanimate environment acts as a 'quasi-emitter' — or, in our terminology, where the interpreted becomes a sign only because it receives an interpretation by the interpretant, which is a response receiver interpretation is dialogic. Not only is there dialogue in semiosis of communication (T. v. Uexküll 1997), where the interpreted itself, before its interpretation as a sign by the interpretant, is an interpretant response directed at being interpreted as a sign. But also there is dialogue in semiosis of symptomatization (T. v. Uexküll 1997), in which the interpreted itself is an interpretant response (symptom) that is not directed at being interpreted as a sign, as well as in semiosis of information or signification. Dialogue does not commence with signaling behaviour from a sender intending to communicate something about an object. The whole semiosic process is dialogic. 'Dialogic' may be intended as dia-logic. The logic of semiosis as a whole and consequently of Krampen's semiosic matrix is a dia-logic. The interpretant as such is 'a disposition to repond', an expression used by Krampen (1997: 259) to describe the dialogic interaction between a sender and receiver.

Krampen's semiosic matrix in fact confirms the connection we have established between dialogue and semiosis. In fact, it shows that the two terms coincide not only in the sense that dialogue is semiosis, but also in the sense that semiosis is dialogue, an aspect which Krampen would seem not to see. The dialogue process presented in the semiosic matrix is similar to the 'if ... then' semiosic process, to hypothesis formation, chain of thought, and functional cycle after Jakob von Uexküll. In the article by Krampen, the semiosic matrix illustrates dialogue with two squares which represent the two partners, that is the sender and the receiver, where each has its own rhombus representing the interpretant. Despite this division, the graphic representation of dialogue is not different from the author's diagrams representing other types of semiosis. It could be the model, for example, of an 'if ... then' semiosis in which the two distinct interpretants are the premises and the conclusion of an argument in a single chain of thought. 


\section{Dialogism and the 'functional cycle'}

J. von Uexküll's (1973) 'functional cycle' is a model for semiosic processes. As such it too has a dialogic structure and involves inferences of the 'if ... then' type which may even occur on a primitive level, as in Pavlovian semiosis or as prefigurements of the type of semiosis (where we have a 'quasi-mind' interpreter) taking place during cognitive inference.

In the 'functional cycle' the interpretandum produced by the 'objective connecting structure' becomes an interpretatum and (represented in the organism by a signaling disposition) is translated by the interpretant into a behavioural disposition which triggers a behaviour onto the 'connecting structure'. The point we wish to make is that in the 'functional cycle' thus described a dialogic relation is established between an interpreted (Interpretandum) and an interpretant (interpreted by another interpretant, and so forth) which does not limit itself to identifying the interpreted, but establishes an interactive relation with it.

Vice versa, not only does the 'functional cycle' have a dialogic structure, but dialogue in communication understood in a strict sense may also be analyzed in the light of the 'functional cycle'. In other words, the dialogic communicative relation between a sender that intends to communicate something about an object and a receiver may in turn be considered on the basis of the 'functional cycle' model. The type of dialogue in question here corresponds to the processes described by the 'functional cycle' as presented, in Th. von Uexküll's terminology, neither in semiosis of information or signification nor in semiosis of symptomatization but in semiosis of communication. Here the interpreted itself, before its interpretation as a sign by the interpretant, is an interpretant response addressed to somebody both to be identified and to receive the required interpretant of answering comprehension.

The theory of an autopoietic system is incompatible with a trivial conception of dialogue, whether this is based on the communication model which describes communication as a linear causal process moving from source to destination, or on the conversation model governed by the turning around together rule. Also, the autopoietic system calls for a new notion of creativity. Otherwise, one may ask with Nöth (1990: 180): 'how are processes such as creativity and learning compatible with the principle of autonomous closure?' As 
Maturana (1978: 54-55) would suggest, creativity and dialogic exchange as opposed to communication understood as a linear process from source to destination or as a circular process in which the participants take turns in playing the part of sender and receiver, should be conceived as 'pre- or anticommunicative interactions'.

\section{Another contributor to semiotics}

We have already stated that in Semiotik/Semiotics a direct analysis of the concept of 'dialogism' is lacking. This weak point may be attributed to the fact that these pivotal concepts as developed by Bakhtin and his collaborators are not held in due consideration in this handbook, which nevertheless deals with the theory of signs in Mikhail M. Bakhtin and his 'Circle'. Bakhtin's semiotic conception is explained in Article 114 ('Der Russische Formalismus' ['Russian Formalism']), by Rainer Grübel (1998) which assembles under this title various other topics, including Vladimir Propp, Lev S. Vygotskij, Gustav Špet, Mikhail Bakhtin and his Circle as well as Russian Formalism. Other Russian contributions to the study of signs such as those by Roman Jakobson, Nikolaj Trubetzkoj, Juri M. Lotman and the Moscow-Tartu School are suitably treated in Articles 115, 'Prague functionalism' (Winner 1998), 116, 'Jakobson and structuralism' (Rudy, Waugh 1998), and 118, 'Die Schule von Moskau und Tartu' ('The Moscow-Tartu School', Fleischer 1998).

\section{Dialogism and biosemiosis}

In Bakhtin's view dialogue consists of the fact that one's own word alludes always and in spite of itself, whether it knows it or not, to the word of the other. Dialogue is not an initiative taken by self. As clearly emerges from novels by Dostoevsky, the human person does not enter into dialogue with the other out of respect for the other, but rather and even predominantly out of contempt for the other. Even a person's identity is dialogic. As we read in the entry 'Dialogism' in the Encyclopedia of Semiotics (Bouissac 1998), 'even the self cannot coincide with itself, since one's sense of the self is essentially a dialogic configuration' (Fielder 1998: 192). The author then quotes a statement made by Bakhtin in 'Discourse in the Novel' (1934, in 
Bakhtin 1981: 341): 'The ideological becoming of a human being [...] is the process of selectively assimilating the words of others' (Fielder 1998: 192). They also quote a statement by Voloshinov 1986: 86: 'word is a two-sided act. It is determined equally by whose word it is and for whom it is meant. As word, it is precisely the product of the reciprocal relationship between speaker and listener, addresser and addressee', with the comment that 'communication is grounded in dialogism' (Fielder 1998: 192).

The word and the self alike are dialogic in the sense that they are passively involved with the word and self of the other. Self is implied dialogically in otherness, just as the 'grotesque body' (Bakhtin 1965) is implied in the body of the other. In fact, dialogue and body are closely interconnected. Bakthin's dialogism cannot be understood separately from his biosemiotic conception of sign on which basis he criticizes both subjective individualism and objective abstraction. According to Bakhtin, there cannot be dialogism among disembodied minds. Unlike platonic dialogue, and similarly to Dostoevsky, for Bakhtin dialogue is not only cognitive and functional to abstract truth, but rather it is a life need grounded in inevitable entanglement of self with other.

Dialogue is not a synthesis of multiple points of view, indeed it is refractory to synthesis. Therefore, Bakhtin opposes dialogue to unilinear and monologic dialectics. Dialogism emerges here as another configuration of logic which contrasts with both formal logic and dialectic logic and their monologic perspective. All this is excellently expressed by the author of the entry 'Dialogism' (Fielder 1998: 192) when he says that the term 'dialogic' must be understood not only as dialog-ic but also as dia-logic:

Understood in this way, dialogism undercuts the hegemonic assumption of a singular, rational form of logic. Bakhtin does not accept the linear, teleological trajectory of simplistic dialecticism, particularly the assumption that synthesis is actually ever realizable. Final and absolute agreement is not possible. Even the self cannot coincide with himself, since one's sense of the self is essentially a dialogic configuration. (Fielder 1998: 192)

Interpretation of the term 'dialogic' as 'dia-logic' validates our conviction (discussed elsewhere) that Bakhtin's main interpreters Holquist, Todorov, Krysinsky, Wellek, etc., - have all fundamentally misunderstood Bakhtin and his concept of dialogue (cf. Ponzio's presentation in Bakhtin 1997). And this is confirmed by the fact that 
they compare Bakhtin's concept of dialogue to its formulation by Martin Buber, Jean Mukarovsky, Plato. Above all, they all understand dialogue in the abused sense of encounter, agreement, convergence, compromise, synthesis. It is symptomatic that Todorov (1981) should have replaced the Bakhtinian term 'dialogue' with 'intertextuality', and 'metalinguistics' with 'translinguistics'.

Intertextuality reduces dialogue to a relation among utterances, while translinguistics, which unlike linguistics focuses on discourse rather than on language (langue), reduces the critical instance of metalinguistics to a sectorial specialization. This approach minimizes the revolutionary capacity of Bakhtin's thought - if it does not completely annul it! The 'Copernican revolution' operated by Bakhtin on a philosophical level and by Dostoevsky on an artistic level, concerns the human being as he is involved with his entire life, needs, thoughts, and behaviour in the life of others, not only the human other, but all living beings.

By contrast with Kant's 'critique of pure reason' and Sartre's 'critique of dialectic reason', Bakhtin inaugurates a 'critique of dialogic reason'.

Consciousness implies a dialogic relation including a witness and a judge. This dialogic relation is not only present in the strictly human world but also in the biological. Says Bakhtin:

When consciousness appeared in the world (in existence) and, perhaps, when biological life appeared (perhaps not only animals, but trees and grass also witness and judge), the world (existence) changed radically. A stone is still stony and the sun still sunny, but the event of existence as a whole (unfinalized) becomes completely different because a new and major character in this event appears for the first time on the scene of earthly existence - the witness and the judge. And the sun, while remaining physically the same, has changed because it has begun to be cognized by the witness and the judge. It has stopped simply being and has started being in itself and for itself [...] as well as for the other, because it has been reflected in the consciousness of the other [...]. (Bakhtin 1970-1971: 137)

For Bakhtin dialogue is the embodied, intercorporeal expression of the involvement of one's body, which is only illusorily an individual, separate, and autonomous body, with the body of the other. The image that most adequately expresses this is that of the 'grotesque body' (cf. Bakhtin 1965) in popular culture, in vulgar language of the public place, and above all in the masks of carnival. This is the body in its vital and indissoluble relation to the world and to the body of others. 
The shift in focus from identity (whether individual, as in the case of consciousness of self, or collective, that is, a community, historical language, or cultural system at large) to alterity is a sort of Copernican revolution in itself (see Ponzio 1997a). With such a shift Bakhtinian critique of dialogic reason calls into question not only the general orientation of Western philosophy, but also the dominant cultural tendencies that engender it.

\section{The 'great experience' in Bakhtin's view of dialogism}

In human beings architectonics becomes an 'architectonics of answerability', a semiotic consciousness of 'being-in-the-world-withoutalibis'. It may be limited to a small sphere - i. e., a restricted life environment of the single individual, one's family, professional, working, ethnic religious group, culture, contemporaneity - or instead it may extend, as 'global semiotic' (the term is Sebeok's) consciousness, to the whole world in a planetary or solar, or even (as hoped by Victoria Welby) cosmic sense. Bakhtin distinguishes between 'small experience' and 'great experience'. The former is narrow-minded experience. Instead,

$[\ldots]$ in the great experience, the world does not coincide with itself (it is not what it is), it is not closed and finalized. In it there is memory which flows and fades away into the human depths of matter and of boundless life, experience of worlds and atoms. And for such memory the history of the single individual begins long before its cognitive acts (its cognizable 'Self'). (Bakhtin's 'Notes of 1950', in Bakhtin 1996: 99. Eng trans., our own)

We must not forget that in 1926 Bakhtin authored an article in which he discussed the biological and philosophical subject. This article appeared under the name of the biologist I. I. Kanaev, but unfortunately it is not even mentioned in the entry on Bakhtin included in Encyclopedia of Semiotics. In any case, this article is an important tessera for the reconstruction of Bakhtin's thought since his early studies. Similarly to the development of research by the biologist Jakob von Uexküll, in Bakhtin too we find an early interest specifically in biology in relation to the study of signs.

The article on vitalism was written during a period of frenzied activity for Bakhtin during the years 1924-1929, in Petersburg, then Leningrad. 
In this productive period of his life he published four books on different subjects (Freud, Russian Formalism, philosophy of language, Dostoevsky's novel), of which only the last under his name, while the others (together with several articles) were signed by Voloshinov or Medvedev. Among Bakhtin's early articles we find 'Contemporary vitalism', of 1926, published in two parts in the popular scientific Russian journal Man and Nature (Nos. 1 and 2), signed by his friend, the biologist Kanaev. Bakhtin's authorship of 'Contemporary vitalism' has never been disputed.

Bakhtin's life in Leningrad was very difficult. Given the increasing seriousness of his illness (osteomyelitis) he qualified for a state pension which, however, was meager. Bakhtin lived in his new friend Kanaev's apartment for several years, from 1924 until 1927, where with his wife he occupied a big but sparsely furnished room described by Konstantin Vaginov, another friend from the 'Bakhtin Circle', as follows: 'Two motley blankets / Two shabby pillows / The beds stand side by side! But there are flowers in the window [...]. Books on the narrow shelves / And on the blankets people / A pale, bluish man / And his girlish wife' (Vaginov, 'Dva pestrykh odeyala...', quoted in Clark, Holquist 1984: 99).

Kanaev contributed to Bakhtin's interest in biology. Thanks to Kanaev Bakhtin, as he says in a note to his text 'Forms of time and the chronotope in the novel' (1937-1938, in Bakhtin 1981: 84), attended a lecture on the 'chronotope' in biology in the summer of 1925, held by the Leningrad physiologist Ukhtomsky. This lecture influenced Bakhtin's conception of the chronotope in the novel. And as Bakhtin further clarifies, 'in the lecture questions of aesthetics were also touched upon'. Ukhtomsky was also an attentive reader of Dostoevsky from whose novel the Double he derived his conception of the double's ghost as an obstacle to comprehending the interlocutor.

Bakhtin owes to the biological research of his time such as that carried out by Ukhtomsky (1966), the view of the relation of body and word as a dialogic relation in which the body responds to its environment modeling its world.

From this point of view Bakhtin's research can be associated with Jakob von Uexküll's. The latter is named in Bakhtin's text signed by Kanaev as one of the representatives of vitalism. In reality, Uexküll kept away from total adhesion to vitalism just as he remained constantly critical of conceptions of the behaviouristic and mechanistic type. As he was to state in his book of 1934 (cf. J. Uexküll 
1967), he was not interested in how the organism-machine works but how the driver works. And Uexküll too was to find an explanation to life in the sign.

We may state, therefore, that both Uexküll and Bakhtin face the question of life in a semiotic perspective. Even if Bakhtin was to increasingly concern himself with problems connected with the literary sign, his dialogism is conceived in the context of research in biology, physiology (precisely the study of the central nervous system - Petersburg was one of the world centers in this field), physics, as well as in psychology and psychoanalysis. In particular, his concept of dialogism cannot be understood if it is not placed, with Uexküll's research in biology, on the line of development that leads to the contemporary field of biosemiotics (cf. T. v. Uexküll 1998: 21892190).

In 'Contemporary vitalism' Bakhtin's criticism of vitalism, that is, the conception which theorizes a special extramaterial force in living beings as the basis of life processes, is turned against Henry Bergson and specifically against the biologist Hans Driesch. The latter stated the difference between life and non-life and interpreted the organism's homeostasis in terms of radical autonomy from its surrounding environment. On the contrary, in his description of the interaction between organism and environment, Bakhtin, opposing the dualism of life force and physical-chemical processes, maintains that the organism forms a monistic unit with the surrounding world.

In his works of the 1920s Bakthin criticizes both the vitalists and the reflexologists, as well as both Freudianism and mechanistic materialism (for instance the mechanistic view of the relation between base and superstructure). In Bakhtin's view, each of these different trends are vitiated by false scientific claims which underestimate the dialogic relation between body and world, which results in either dematerializing the living body or physicalizing it in terms of mechanistic relations. Bakhtin's reflection on signs is fundamental to such a critique. Reference to signs contributes to an understanding of both living and psychic processes as well as historical-cultural relations, such as that between base and superstructure. Another contribution to an adequate understanding of these processes ensues from replacing both unilinear and conclusive mechanical dialectics with the dialogic model. Jakob von Uexküll's research develops in the same way. For both Bakhtin and Uexküll the process under examination is a semiosic process. Though Uexküll does not use the 
dialogic model explicitly, we have seen above how it is central to his famous 'functional cycle'.

\section{Dialogism and the biosemiotic view in the 'Rabelaisian world'}

Rabelais occupies a place of central importance in the overall architectonics of Bakhtin's thinking. In contrast with oversimplifying and suffocating interpretations of Marxism, Bakhtin works on Marx's idea that the human being only comes to full realization when 'the reign of necessity ends'. Consequently, a social system that is effectively alternative to capitalism is one which considers free time, available time, and not work time, as the real social wealth (see Marx 1974 [1857]). In Bakhtin's language this is the 'time of non official festivity', which is closely connected to what he calls the 'great time' of literature.

Today's world of global communication is dominated by the ideology of production and efficiency. This is in complete contrast with the carnival worldview. Exasperated individualism associated with the logic of competition also characterizes the world of global communication. However, as much as production, efficiency, individualism, competition now represent dominant values, the structural presence of the grotesque body founded on intercorporeity, involvement of one's body with the body of others, cannot be ignored. The human being's vocation for the 'carnivalesque' has resisted. Literary writing testifies to this. Indeed, in Orwell's 1984, the ultimate resistance to a social system dominated by the values of production and efficiency is offered by literature. In this sense we may say that literature (indeed art in general) is and always will be carnivalized.

To conclude: modeling and dialogism are pivotal concepts in the study of semiosis. Communication, information or signification, and symptomatization are all forms of semioses that presuppose modeling and dialogism. This is particularly evident if, in accordance with Peirce (who reformulates the classic notion of substitution in terms of interpretation), we consider the sign firstly as an interpretant, i.e. a dialogic response foreseen by a specific type of modeling. 


\section{Binarism, triadism and dialogism}

Concerning binarism in semiotics, the scope of semiotic enquiry as it appears in Semiotik/Semiotics as well as in Sebeok's global semiotics undoubtedly transcends the opposition between the semioticians with a Saussurean/Hjelmslevian/Greimasian orientation (see Larsen 1998; Johansen 1998; Parret 1998) and the semioticians of Peircean observance (cf. Pape 1998; and Paul Bouissac's article 'Semiotic terminology', in Bouissac 1998: 568-571). These two factions would seem to oppose binarism to triadism. However, the volumes forming Semiotik/Semiotics would seem to confirm our opinion that the heart of the matter does not at all lie in the opposition between binarism and triadism. Instead, of focal importance we believe is the opposition between a model of sign that tends to oversimplify things with respect to the complex process of semiosis and a semiotic model (as prospected by Peirce) that would seem to do more justice to the various aspects and factors of the process by which something is a sign. This is not merely achieved on the basis of an empty triadic form, but rather thanks to the specific contents of Peirce's triadism, in other words, thanks to the categories his triadism in fact consists of, the typology of sign it proposes, the dynamic model it offers by describing signs as grounded in renvoi from one interpretant to another. The categories of 'firstness', 'secondness', and 'thirdness', the triad 'representamen', interpretant', and 'object', characterization of the sign on the basis of its triple tendency towards symbolicity, indexicality, and iconicity, enable us to emphasize and maintain in a semiotic perspective the alterity and dialogism constitutive of signs. In previous books and papers we have attempted to highlight the dialogic and polylogic character of Peircean logic. The merit does not go to the triadic formula. Proof for this is offered by Hegelian dialectic in which triadism, abstracted as it is from the constitutive dialogism of sign life, gives rise to metaphysical, abstract and monological dialectic. It is odd that in the entry 'Binarism' in Encyclopedia of Semiotics, the author should propose Hegelian philosophy as a means of overcoming the theory of binary opposition in Lévi-Strauss's structuralism (cf. Thibault 1998: 81). Bakhtin, in his 1970-1971 notebooks, gives a good explanation of how Hegelian monological dialectic is formed, showing how it actually has its roots in a vital dialogic sign context. The process consists in taking out the voices (division of voices) from dialogue, eliminating any (personal/emotional) intonations, and thus 
transforming live words into abstract concepts and judgements, so that dialectic is obtained in the form of a single abstract consciousness. Peirce himself also took a stand against the systemic skeleton of Hegelian analysis, against dialectic intended as a kind of hypochondriac search for an end, that is, as being oriented unilaterally instead of being open and contradictory (on the relation between dialogue and dialectic in Peirce and Bakhtin, see Bonfantini, Ponzio 1986; Bonfantini et al. 1996).

The alternative in semiotics is not between binarism and triadism, but between monologism and polylogism.

\section{Language and writing}

In Sebeok's view language was exapted for communication 'into speech, and later still, into other linear manifestations, such as script' (Sebeok 1997: 443). We have proposed (Ponzio et al. 1999) a distinction between 'script' or 'transcription' and 'writing'. In our opinion this distinction is as important as that between language and speech. We may use the term 'writing' for that characteristic of language understood as human modeling designated by Sebeok with the term 'syntax'.

Without distinguishing between script and writing — writing avant la lettre - it is not possible to free the mind from the widespread prejudice that in today's society writing is overwhelmed by other sign forms. Part of this prejudice is the thesis that nowadays the image dominates over writing, as though all forms of human sign production were not as such forms of writing. The fact is that we have a restricted view of writing. Accordingly, writing is identified with the transcription of oral language, which it merely registers, appearing as a sort of outer covering, subaltern and ancillary with respect to orality.

Thus considered writing is no more than mnemotechny (as in Plato). Such a restricted view is not only connected to the preconceived idea of the primacy of the oral word, of the phoné, and therefore to a prejudicial phonocentric order. It is also connected to a prejudicial view of an ethnocentric order. According to this perspective, writing - reduced to the status of transcription - would wrongly seem to be the prerogative of certain social forms and not others. It is thought to represent a fundamental stage in human history, a discriminating factor between prehistory and history, between 'cold' 
societies devoid of history and 'warm' societies endowed with history, capable of evolution and historical memory.

Writing understood as transcription is connected to 'culture' in a narrow sense, according to which writing is opposed to 'non culture' and is thought to belong to the 'man of culture', with all the connections that writing thus described has with power and with the consolidation of relations of dominion of man over man. On the contrary, the capacity for writing as a species-specific capacity belongs to 'culture' in a broad sense, in an anthropological sense which opposes writing to 'nature', attributing it to man as such.

In reality, the invention of writing as transcription presupposes writing understood in a far more complex sense, and in a far broader temporal sphere than man's historical-cultural evolution, given that it concerns the very process of hominization, that is, the formation and evolution of the human species. Writing is a human species-specific modeling device through which the human being, resorting to various means - including one's body or external physical means -, organizes experience as well as surrounding reality both spatially and temporally conferring sense upon them and constructing whole worlds. The human being is capable of inventing new senses and constructing different worlds with the same means and elements. All animal species construct their own worlds in which things take on a given sense; the distinctive feature of the human species lies in the capacity to confer different senses upon the same elements, even limited in number, and to construct a plurality of possible worlds.

Thus intended the capacity for writing, 'ante litteram' writing, writing antecedent to the written sign, to transcription, represents a fundamental stage in the hominization process antecedent to speech which is privileged with respect to other - even earlier - means of communication. Writing thus understood is not a means of communication like speaking and its transcription, but rather precedes and is the foundation of all forms of communication.

The development of speech and of relative verbal systems, that is, languages, presupposes writing. Without the capacity for writing man would not be in a position to articulate sounds and identify a limited number of distinctive features, phonemes, to be reproduced phonetically. Without the capacity for writing humans would not know how to assemble phonemes in different ways so as to form a great multiplicity of different words (monemes), nor would they know how to assemble words syntactically in different ways so as to form 
utterances that are always different, expressing ever different meanings and senses.

And when, as in the case of deaf-mutes, the development of writing in the phonic form is impossible, writing - if adequately elicited - finds other possibilities of grafting (gesture, drawings) which (at times) allows for the noteworthy development of the language capacity unaccompanied by speech.

Today we are witnesses to a noteworthy development in languages which proliferate thanks to developments in technology as well as to encounters and exchanges among different cultures (closed frontiers and the assertion of community identity cannot obstacle such encounters and exchanges which obviously go far beyond market exchange). Nowadays writing understood in the broad sense described above has greater possibilities of manifesting itself in different ways. And thanks to language as described above, photography, cinema, television, videocassettes, computers represent new possibilities of writing increasing our capacity for the 'play of musement'. Furthermore, traditional forms of expression such as theatre, music, the figurative arts may now resort to new developments in technology to invent new forms of writing within their own spheres as well as through processes of reciprocal contamination leading to the formation of new expressive genres. Picture writing, design, photographic writing, film writing, musical writing should now all be reconsidered in this light and viewed as representing high levels in the manifestation and development of the creative need of writing understood as the capacity for language.

There is no question of the crisis of writing. No other historical era has ever been so rich in writing as the present. We are now living in the civilization of writing. And this fact should be stated emphatically to anyone who, confounding writing and the written sign, writing and transcription, should complain - through ignorance or for ideological reasons - about the 'loss' or 'debasement' of 'writing'.

These days what we especially need is a commitment to achieving the right conditions for the spread and free growth of writing systems, delivering them from any form of subjection to whomever holds control over communication. This is the real problem for education in writing. It is not a question of falsely opposing 'writing' to the 'image' in current forms of communication, but of the objective contradiction between continuing increase and expansion of writing, languages, the free 'play of musement' and increasing control over 
communication, which is also increasing concentration of such control in the hand of a few.

Literary writing is another important place, and perhaps the earliest, where writing attains independence from transcription, that is, where the written sign attains independence from its ancillary function with respect to oral language, and therefore where writing is no longer reduced to mnemotechny. Today other forms of writing develop and supplement the work of literary writing.

Disengagement of literary writing, that is, disengagement with respect to the obligations characterizing other genres where writing figures as mere transcription, frees it from defined and circumscribed responsibilities, delimited by alibis. As writing and not as transcription, literary writing is refractory to any form of power that may obstacle it (see Orwell 1949). Such disengagement from (technical) partial and relative responsibility charges literary writing with the kind of (moral) responsibility that does not know limits (Bakhtin). This delivers man from all that which may obstacle the free manifestation of what characterizes him in his specificity as a human being: language, in other words, the possibility of the infinite play of constructing — and deconstructing - new possible worlds. The human lies in this nonfunctional, unproductive, freely creative play of writing, independent of need, an excess in relation to functionality, productivity, external to the 'reign of necessity' (Marx).

\section{On the dimensions of semiosis: syntactics, semantics, and pragmatics}

In Semiotik/Semiotics, Chapter II, 'Systematics' (next after Posner's presentation), deals with the tripartition of semiotics into the three branches of syntactics, semantics and pragmatics (articles 2-4, respectively Posner, Robering 1997; Robering 1997; Posner 1997b).

It was Charles Morris (1938) who introduced this tripartition into semiotics, but the historical origins of these branches can be traced back to the artes dicendi, i.e., grammar, rhetoric, and dialectic, taught as part of the so-called trivium in Medieval European schools.

Morris's trichotomy is related to Peirce's, who distinguished between speculative grammar, critical logic — the successor of dialectic - and methodeutic - the successor of rhetoric (cf. CP 1.191ff and 2.93). Thus Peirce reinterpreted the artes dicendi as 
branches of semiotics and systematized these as disciplines that treat signs as Firstness, Secondness, and Thirdness, respectively (cf. $S / S, 1$ : 4). In this sense, semiotics consists of three subdisciplines: 'speculative grammar', which gives us a physiognomy of forms, a classification of the function and form of all signs; 'critic', the study of the classification and validity of arguments (divided into three parts: the logic of abduction, induction and deduction); and 'methodeutic', the study of methods for attaining truth. Pragmatism, which is based on the thesis that the meaning of a sign can be explicated by considering its practical consequences as the response of an interpretant, is a methodeutic theory in Peirce's sense (cf. Pape 1998: 2020).

As Posner (1997b) notes, although Morris's trichotomy is related to Peirce's, it is also motivated by reference to three leading philosophical movements of his time, Logical Positivism, Empiricism, and Pragmatism.

In Morris 1938, the three branches of semiotic, syntactics, semantics, and pragmatics, correspond respectively to the three dimensions of semiosis, the syntactical, the semantical and the pragmatical.

According to a tradition that goes back to Michel Bréal's sémantique (1897) understood as 'the science of significations', meaning is generally associated with the semantical dimension of semiosis. On the contrary, however, meaning is present in all three dimensions including the syntactical and pragmatical and to state that it belongs uniquely to the semantical is the result of a misunderstanding. When Morris claims that syntactics deals with relations among signs, this does not exclude that it involves meaning, which too is part of the relation among signs. Similarly, as much as pragmatics focuses on the relation of signs to interpreters, as says Morris, it too deals with signs and therefore with meanings (cf. Rossi-Landi 1994 [1972] which includes his paper of 1967, 'Sul modo in cui è stata fraintesa la semiotica estetica di Charles Morris').

To restrict meaning to the semantical dimension of semiosis instead of tracing it throughout all three dimensions is to reduce the sign totality to one of its parts only, in the case of semantics to the relation of designation and denotation. Similarly, the relation of the sign to other signs does not only concern the syntactical dimension in a strict sense to the exclusion of the pragmatical and the semantical, just as the relation of the interpreter to other interpreters does not uniquely concern the pragmatical dimension to the exclusion of the syntactical and the semantical. Each time there is semiosis and, 
therefore, a sign, all three dimensions are involved and are the object of semiotics.

\section{Syntactics and syntax}

'Syntactics' covers the syntactical aspects of signs, their formal aspects, relations and combinations, including texts, pieces of music, pictures, industrial artifacts, and so on. As specified in this article and in accord with our observations anticipated above in our discussion on 'syntax' (in Sebeok's sense), in linguistics, phonology, syntax (in the strict sense) and the morphology of natural language all fall under syntactics. Syntactics includes morphology as well as syntax.

An example of syntactics as the study of combination rules to form complex signs is in Posner and Robering's view Chomsky's transformational grammar which studies rules of transformation from 'deep structures' to 'surface structures' (Posner, Robering 1997: 33-37).

This distinction (introduced in Chomsky 1965), as well as the previous between 'nuclear' and 'non-nuclear sentences' (Chomsky 1957), is connected with a very questionable conception of language and knowledge and with an equally questionable method of analysis (cf. Ponzio 1973, amplified French. ed. 1992; 1997b: 313-320; 2001). In a context such as that offered by the Semiotik/Semiotics handbook, it would not have been out of place to signal some narrow ideas in Chomsky's linguistics. Apart from previous criticism, his limits in linguistics quite inevitably emerge in the light of a Peircean and Morrisian approach to the study of signs.

Chomsky's theoretical framework is lacking in those methodological features characteristic of a scientific sign theory enumerated in articles on semiotic method (see above). Chomsky sees no alternative to vulgar linguistic behaviourism (such as Skinner's), other than appealing to the rationalistic philosophy of the seventeenth century, and taking sides with mentalism and innatism. That the Chomskyan conception of language remains tied to the classical alternatives between consciousness and experience, rationalism and empiricism is not without negative consequences for a theory of language, even with respect to such a specialized branch as syntax. In this sense Chomsky's approach is alien to both Kantian criticism and along the same lines, to the conceptions of Edmund Husserl, Peirce, Ernst 
Cassirer, Maurice Merleau-Ponty, Morris, etc. (see $\S 2$, 'Kants Lehre vom Zeichen', Scheffczyk 1998: 1430-1431).

Unlike Chomsky's dichotomy between linguistic competence and experience, in modern conceptions after Kant experience is described as a series of interpretive operations. These include inferential processes of the abductive type (Peirce) through which the subject completes, organizes, and associates data which are always more or less fragmentary, partial, and discrete. Experience is these operations as such is innovative and qualitatively superior by comparison with the limited nature of eventual input. After all, experience coincides with competence. What Chomsky (1986) baptized 'Plato's problem' is a consequence of the false dichotomy between competence and experience as well as of the ensuing conception of experience as a passive state of the subject.

Morris's concept of syntactics as well as the notion of syntax which belongs to it are connected with semantics and pragmatics. Instead, Chomsky's syntax - as well as his phonology and semantics (morphology) - belongs to syntactics equated with syntax, as in Carnap, and separated from semantics and pragmatics.

Moreover, Chomsky confuses levels of analysis, mistaking the description of the objects of analysis for the construction of the models of analysis. In this sense, Chomsky's linguistics is a unigradual linguistic theory which, unlike Rossi-Landi's (1998 [1961]) 'methodics of common speech' (see Ponzio 1988; 1990a) or Shaumyan's (1987) bigradual theory of generative grammar, fails to distinguish between the genotypical level and the phenotypical level. This is a serious limit in the hypothetical-deductive method, or more properly, recalling the Peircean concept of 'abduction', in the abductive method.

Chomsky's error is no different from that of Oxonian analytical philosophy, which claimed to describe ordinary, daily, or colloquial language in general while, in reality, describing the characteristics of a given natural language. Such confusion between two levels, the general and abstract level of language and the particular and concrete level of a given language at a given moment in its historical development, is recurrent - and not only in the Oxonian conception or in more recent analyses of language inspired by the latter. Chomskyan generative grammar, too, mistakes the specific characteristics of a language - yet again English - for the universal structures of human language. The untranslatability of sentences used by Chomsky as examples of his analyses is symptomatic of the problem 
at hand. The transformational model proposed by Chomsky confuses elements that in fact belong to two different degrees of abstraction, ideal language and natural language.

Thus Chomskyan grammar with its methodologic suppositions and dualism between competence and experience and between deep structures and surface structures, would not seem to offer a suitable example of syntactics $_{3}$ as understood by Posner and Robering (1997: 14) and in accord with Morris's approach to semiotics. Elsewhere (Ponzio 1990; 1997b; 2001) we have proposed, as a branch of syntactics which studies combination rules applied to verbal form complexes, an 'interpretive linguistic theory' able to 'generate' (in Chomsky's sense) an utterance in terms of its relation to another utterance that interprets it, an utterance that acts as interpretant. In fact, all utterances are engendered, that is, produced, identified and characterized by their interpretants. According to this approach, the interpretant of a 'sentence' (the dead cell of linguistic system) or, as we prefer, 'utterance' (the live cell of discourse) is not a deep structure grounded in underlying elementary sequences, but another verbal sign. An interpretant identifying an utterance or any verbal sign whatever is simply 'unexpressed' until the conditions are realized for its expression, explicitation'. We have introduced the expression 'identification interpretant' (cf. Ponzio 1990) for this type of interpretant which

(a) identifies the verbal sign in its phonemic or graphic features;

(b) identifies the verbal sign in its semantic content;

(c) identifies the morphological and syntactic physiognomy of the verbal sign.

Given that the three dimensions of semiosis (syntactical, semantical and pragmatical) are inseparable, the interpretant engendered by an utterance or any verbal sign whatever is not only an identification interpretant. It is also an 'answering comprehension interpretant' which has a special focus on the pragmatical dimension of signs. Without the interpretant of answering comprehension, it is difficult or even impossible to recognize the sign at the level of phonemic or graphemic configuration, morphological and syntactic structure, as well as semantic content.

Just as we have highlighted the presence of syntactics in all aspects of signs, in the same way we must underline that the question of meaning (i.e., of the relation between interpreted and interpretant) is also present at the level of identification of the units composing words, phrases, utterances and texts. 


\section{The referent as designatum and denotatum}

Concerning the semantic dimension we wish to remember the important contribution made by Morris to sign theory in relation to the issue of the referent. At a given moment in the recent history of semiotics referential semantics was contrasted to nonreferential semantics. The starting point of the debate was Ogden and Richards's famous but often deviating triangle with its distinction between the three apexes denominated 'symbol', 'thought or reference' and 'referent'. Under the influence, among other things, of Saussure's binary conception of sign as the relation of a signifiant to a signifie, meaning was described as the relation of a 'symbol' to 'thought or reference'

Thus the question under debate became whether or not the 'referent' should be eliminated from this triangle. Supporters of nonreferential semantics included Stephen Ullmann (1962) and Umberto Eco (1975). Subsequently, Eco (1984) became aware of the need to recover the concept of referent and did so implicitly by resorting to the Jakobsonian concept of renvoi.

In any case, if we accept Morris's distinction between designatum and denotatum the question of the referent and its misunderstandings are easily solved. This distinction was originally proposed by Morris in his 1938 book, Foundations of the Theory of Signs.

'Where what is referred to actually exists as referred to the object of reference is a denotatum', says Morris (1971: 20). For example, if the sign 'unicorn' refers to its object considering it as existent in the world of mythology, that sign has a denotatum since unicorns do exist in mythology. On the contrary, if the sign 'unicorn' refers to its object considering it as existent in the world of zoology, that sign does not have a denotatum since unicorns do not exist in zoology. In this case the sign has a designatum (Morris 1938), or a significatum, as Morris (1946) was later to call it (see below), but it does not have a denotatum. 'It thus becomes clear that, while every sign has a designatum, not every sign has a denotatum' (Morris 1971: 20). By using Morris's distinction between designatum and denotatum misunderstandings in regard to the referent can in fact be avoided.

In other semantic theories, the referent is eliminated altogether on the basis of the fact that what the sign refers to does not always exist in the terms referred to by the sign. In this case the designatum is obviously not taken into account. On the contrary, as has been amply demonstrated (Calabrese et al. 1993; Ponzio 1985; 1990; 1997b; 
Ponzio et al. 1999), the sign has a referent always, or in Morris's terminology, a designatum, and if this referent exists in the terms referred to by the sign, it also has a denotatum.

Indeed, the object of reference, referent, or Object in Peirce's sign triad, is a component of semiosis. In Ponzio (1990: 33-36) we proposed to consider the referent as an implicit interpretant. In other words, the referent of a sign is another sign to which the former refers implicitly. Once explicited, the referent changes position and becomes an interpretant with an explicative function; while the sign which had a referent, i.e., the sign with implicit meaning, becomes an interpreted.

Referent (object), interpretant, and interpreted (representamen, sign vehicle) are, therefore, three different functions carried out by the sign. A referent is an implicit part of an interpretive route that the explicit part (interpretant) refers to. The impossibility of expliciting all interpretants of a sign given that they are infinite in number (Peirce's 'infinite semiosis') causes every sign to have a referent (implicit interpretant) just as it has meaning (explicit interpretant). Meanings (and therefore signs) without a referent do not exist. Consequently, that the referent, or object of reference, is a component of semiosis, means that the referent is not external to sign reality, even if as a 'dynamical object' it is external to a current semiosis. It is not possible to refer to something without this something becoming part of an interpretive route, i.e., without it being an implicit interpretant or interpreted. Referents are not external to the network of signs.

\section{Pragmatics and the interpretant of answering comprehension}

Morris defined pragmatics as the study of the relations of sign vehicles to interpreters or more simply as 'the relations of signs to their users' (Morris 1938). Unlike Rudolf Carnap (1939) who restricted the field of pragmatics to verbal signs only to include nonlinguistic signs much later (1955), Morris's conception of pragmatics concerns both verbal and nonverbal signs. John L. Austin (1962) and John Searle (1969) also limited their interest in the pragmatical dimension to verbal signs. On the contrary, Morris goes so far as to include the ethic and esthetic dimensions as well. Morris's interest in the relation of signs to values is closely connected with pragmatics which deals with the relation of signs to interpreters. 
Speech act theory (cf. McHoul 1998) 'is both distinct from and to some degree competitive with theories of significatory and systemic difference proposed by the semiotician' (McHoul 1998: 591). In our opinion, the substantial difference between speech act theory and Peircean or Morrisian semiotics is that the former fails to consider two factors in the pragmatic dimension of meaning which, on the contrary, must not be neglected: interpretation and alterity. In other words, speech act theory does not account for the interpretant of answering comprehension. This is a consequence of the fact that the concept of verbal sign (in John L. Austin and John R. Searle) lacks a semiotic foundation.

Stressing the interpretant rather than the interpreter, pragmatics concerns the interpretant which does not merely identify the interpreted, thereby acting as an 'identification interpretant', but responds and takes a stand towards it. This is what we have called the interpretant of answering comprehension, which, unlike the identification interpretant, is specific to a sign interpreting its actual sense. Sign interpretation in terms of answering comprehension opens to interpretive trajectories connected with sense, advancing towards signness or semioticity beyond signality. Rather than use the term 'meaning' in relation to interpretants whose task it is to identify interpreteds, or 'sense' for interpretants whose task is not limited to merely identifying the interpreted, we may distinguish between two zones of meaning, that of signality (the object of syntactics) and that of signness (the object of pragmatics). As anticipated, the interpretant relative to the signal and to signality is the identification interpretant (cf. Ponzio 1985; 1990; 1997b; Ponzio et al. 1999); instead, the interpretant specific to the sign, that which interprets its actual sense has been called respondent or answering comprehension interpretant. This interpretant or this dimension of the interpretant concerns the pragmatical dimension of the sign, that is, the sign as such. The relation between interpreted and the answering comprehension interpretant depends on the models, habits and customs of the world in which the interpreted-interpretant relation is situated. The interpretant of answering comprehension is the conclusion of a line of reasoning in an inferential process with a dialogic structure. Pragmatics deals with the relation between the sign vehicle or 'representamen', the interpreted and the interpretant in its full sign nature, that is, as the interpretant of answering comprehension. 


\section{References}

Austin, John L. 1962. How to do Things with Words: The William James Lectures delivered at Harvard University in 1955. Oxford: Oxford University Press.

Bakhtin, Mikhail M. 1965. Tvorchestvo Fransua Rable. Moscow: Hudozhestvennaja literatura. [Eng. trans. Rabelais and His World. Pomorska, Krystina (ed.). Cambridge: MIT Press, 1968.] [New trans. Iswolsky, Helene. Bloomington: Indiana University Press, 1984.]

- 1970-1971. From notes made in 1970-71. In Bakhtin 1986: 132-158.

- 1981. The Dialogic Imagination: Four Essays. Holquist, Michael (ed.). Austin: University of Texas Press.

- 1986. Speech Genres and Other Late Essays, ed. Caryl Emerson and Michael Holquist. Austin: University of Texas Press.

- 1996. Sobranie sochinenij [collected works], vol. 5 (1940-1960). Bocharovand, S. G.; Gogotishvili, L. A. (eds.). Moscow: Russkie slovari.

- 1997 [1929]. Problemi dell'opera di Dostoevsky [Problemy tvorchestva Dostoevskogo]. Ponzio, Augusto (ed.). Bari: Edizioni dal Sud.

Bakhtin, Mikhail M.; Kanaev, Ivan I.; Medvedev, Pavel; Voloshinov, Valentin N. 1995. Il percorso bachtiniano fino ai 'Problemi dell'opera di Dostoevskij' (1919-29). Ponzio, Augusto; Jachia, Paolo; Michiel, Margherita De (eds.). Bari: Dedalo.

Bonfantini, Massimo A.; Ponzio, Augusto 1986. Dialogo sui dialoghi. Ravenna: Longo.

Bonfantini, Massimo A; Ponzio, Augusto; Petrilli, Susan 1996. I tre dialoghi della menzogna e della verità. Naples: Edizioni Scientifiche Italiane.

Bouissac, Paul (ed.) 1998. Encyclopedia of Semiotics. New York: Oxford University Press.

Bréal, Michel 1924 [1897]. Essai de sémantique: Science des significations. Paris: Hachette.

Calabrese, Omar; Petrilli, Susan; Ponzio, Augusto 1993. La ricerca semiotica. Bologna: Esculapio.

Carnap, Rudolf 1939. Foundations of Logic and Mathematics. (International Encyclopedia of Unified Science 1(3).) Chicago: University of Chicago Press.

Chomsky, Noam 1957. Syntactic Structures. The Hague: Mouton.

- 1965. Aspects of the Theory of Syntax. Cambridge: MIT Press.

- 1986. Knowledge of Language: Its Nature, Origins, and Use. New York: Praeger.

Clark, Katerina; Holquist, Michael 1984. Mikhail Bakhtin. Cambridge: Harvard University Press.

Eco, Umberto 1975. Trattato di semiotica generale. Milano: Bompiani.

- 1984. Semiotica e filosofia del linguaggio. Torino: Einaudi.

Fielder, John 1998. Dialogism. In: Bouissac 1998: 191-193.

Fleischer, Michael 1998. Die Schule von Moskau und Tartu. In: Posner et al. 1998: 2289-2300.

Grübel, Rainer 1998. Der Russische Formalismus. In: Posner et al. 1998: 22332248. 
Husserl, Edmund 1948. Erfahrung und Urteil: Untersuchungen zur Genealogie der Logik. Hamburg: Klaassen Verlag.

Johansen, Jørgen Dines 1998. Hjelmslev and glossematics. In: Posner et al. 1998: 2272-2289.

Kanaev, Ivan I. 1995 [1926]. Il vitalismo contemporaneo. In: Bakhtin et al. 1995: 175-198.

Krampen, Martin 1997. Models of semiosis. In: Posner et al. 1997: 247-287.

Kull, Kalevi 2002. A sign is not alive — a text is. Sign Systems Studies 30(1): 327-336.

Larsen, Svend Erik 1998. Ferdinand de Saussure und seine Nachfolger. In: Posner et al. 1998: 2041-2073.

Lotman, Juri M. 1990. Universe of the Mind: A Semiotic Theory of Culture. London: I. B. Tauris.

Marx 1974 [1857]. Introduzione del '57. [Including the German original, intro. B. Accaro.] Verona: Bertani.

Maturana, Humberto R. 1978. Biology of language: The epistemological reality. In: Miller, George A.; Lenneberg, Elizabeth (eds.), Psychology and Biology of Language and Thought. New York: Academic Press, 27-63.

McHoul, Alec 1998. Speech act theory. In: Bouissac 1998: 591-592.

Morris, Charles William 1938. Foundations of the Theory of Signs. (International Encyclopedia of Unified Science 1(2).) Chicago: University of Chicago Press.

- 1946. Signs, Language and Behavior. New York: Prentice Hall.

- 1971. Writings on the General Theory of Signs. Sebeok, Thomas A. (ed.). The Hague: Mouton.

Nöth, Winfried 1990. Handbook of Semiotics. Bloomington: Indiana University Press.

Orwell, George 1949. 1984. London: Secker and Warburg.

Pape, Helmut 1998. Peirce and his followers. In: Posner et al. 1998: 2016-2040.

Parret, Herman 1998. Greimas and his School. In: Posner et al. 1998: 2300-2311.

Peirce, Charles S. 1931-1966. Collected Papers, ed. Hartshorne, Charles, Weiss, Paul, and Burks, Arthur W., 8 vols. Cambridge: Belknap Press, Harvard University Press. [Cited as $C P$ followed by volume and paragraph numbers.]

Petrilli, Susan 1998. Teoria dei segni e del linguaggio. Bari: Graphis. [2nd ed. 2001.]

Petrilli, Susan; Ponzio, Augusto 2001. Sebeok and the Signs of Life. London: Icon Books.

Ponzio, Augusto 1973. Produzione linguistica e ideologia sociale. Bari: De Donato.

- 1985. Segni per parlare di segni. Signs to Talk about Signs. Eng. trans. S. Petrilli. Bari: Adriatica.

- 1988. Rossi-Landi e la filosofia del linguaggio. Bari: Adriatica.

- 1990. Man as a Sign. Petrilli, S. (ed.). Berlin: Mouton de Gruyter.

- 1992. Production linguistique et idéologie sociale. Candiac: Les Editions Balzac.

- 1997a. La rivoluzione bachtiniana: Il pensiero di Bachtin e l'ideologia contemporanea. Bari: Levante Editori.

- 1997b. Metodologia della formazione linguistica. Bari: Laterza. 
- 2001. Enunciazione e testo letterario nell'insegnamento dell'italiano come LS. Perugia: Guerra.

Ponzio, Augusto; Calefato, Patrizia; Petrilli, Susan 1999. Fondamenti di filosofia del linguaggio. Bari: Laterza.

Posner, Roland 1997a. Semiotics and its presentation in this Handbook. In: Posner et al. 1997: 1-14.

- 1997b. Pragmatics. In: Posner et al. 1997: 219-246.

Posner, Roland; Robering, Klaus 1997. Syntactics. In: Posner et al. 1997: 14-83.

Posner, Roland; Robering, Klaus; Sebeok, Thomas A. (eds.) 1997-1998. Semiotik/Semiotics: A Handbook on the Sign-Theoretic Foundations of Nature and Culture, vols. 1 and 2. Berlin: Walter de Gruyter.

Prodi, Giorgio 1977. Le basi materiali della significazione. Milano: Bompiani.

Robering, Klaus 1997. Semantik. In: Posner et al. 1997: 83-219.

Rossi-Landi, Ferruccio 1994 [1972]. Semiotica e ideologia, ed. Ponzio, Augusto. Milano: Bompiani.

- 1998 [1961]. Significato, comunicazione e parlare comune, ed. Augusto Ponzio. Padua: Marsilio.

Rudy, Stephen; Waugh, Linda 1998. Jakobson and structuralism. In: Posner et al. 1998: 2256-2271.

Scheffczyk, Adelhard 1998. Zeichenkonzeptionen in der Allgemeinen Philosophie vom 19. Jahrhundert bis zur Gegenwart. In: Posner et al. 1998: 1428-1465.

Searle, John R. 1969. Speech Acts: An Essay in the Philosophy of Language. Cambridge: Cambridge University Press.

Sebeok, Thomas A. 1991. A Sign is Just a Sign. Bloomington: Indiana University Press.

- 1994. Signs: An Introduction to Semiotics. Toronto: Toronto University Press.

- 1997. The evolution of semiosis. In: Posner et al. 1997: 436-446.

- 2001. Global Semiotics. Bloomington: Indiana University Press.

Sebeok, Thomas A.; Hoffmeyer, Jesper; Emmeche, Claus (eds.) 1999. Biosemiotica. Special Issue. Semiotica 127(1/4).

Sebeok, Thomas A.; Umiker-Sebeok, Jean (eds.) 1992. Biosemiotics: The Semiotic Web 1991. Berlin: Mouton de Gruyter.

Shaumyan, Sebastian 1987 [1965]. A Semiotic Theory of Language. Bloomington: Indiana University Press.

Thibault, Paul J. 1998. Binarism. In: Bouissac 1998: 76-82.

Todorov, Tzvetan 1981. Mikhail Bakhtine: Le principe dialogique. Paris: Seuil.

Uexküll, Jakob von 1967 [1934]. Ambiente e comportamento. Mondella, Felice (ed.). Milan: Il Saggiatore.

- 1973 [1928]. Theoretische Biologie. Frankfurt am Main: Suhrkamp.

- 1982 [1940]. The theory of meaning. Semiotica 42(1), 25-82.

Uexküll, Thure von 1992. Varieties of semiosis. In: Sebeok, Umiker-Sebeok 1992: 455-470.

- 1997. Biosemiose. In: Posner et al. 1997: 447-457.

- 1998. Jakob von Uexküll's Umweltlehre. In: Posner et al. 1998: 2183-2191.

Ukhtomsky, Aleksej A. 1966. Dominanta [The dominant]. Moscow: Nauka.

Ullmann, Stephen 1962. Semantics: An Introduction to the Science of Meaning. Oxford: Blackwell. 
Vernadsky, Vladimir I. 1926. Biosfera. Leningrad: Nauka.

Voloshinov, Valentin N. 1986 [1929]. Marxism and the Philosophy of Language.

Trans. Matejka, L., Titunik, I. R. Cambridge: Harvard University Press.

Winner, Thomas G. 1998. Prague functionalism. In: Posner et al. 1998: 22482255.

Wirth, Uwe 1998. Abductive reasoning. In: Bouissac 1998: 1-3.

\section{Моделирование, диалог, глобальность: биосемиотика и семиотика самости. \\ 1. Семиозис, моделирование, диалогизм}

Статья предлагает критический обзор положения дел в семиотике, обращая особое внимание на теоретические проблемы, сосредотачивающиеся вокруг соотношения культуры и природы. Другими словами, мы фокусируемся на соотношении понятий семиосферы (Ю. Лотман) и биосферы (В. Вернадский), учитывая разные подходы и предлагая свою точку зрения. Существенным источником при изучении состояния современной семиотики является пособие Semiotik/Semiotics, подзаголовком которого не случайно является Руководство по теоретико-знаковым основам природы и культуры. В этой книге существенна роль Томаса А. Себеока и его понимания семиотики как “глобальной”. Одним из центральных понятий глобальной семиотики Себеока является моделирование, которое пронизывает как природу, так и культуру. Понятие моделирования соединяет два семиозиса - природный и культурный - и приводит к оригинальному определению понятий “семиосфера" и “биосфера". Эта проблематика соотносится и с семиотическими исследованиями в современном Тарту, что находит свое выражение в журнале Sign Systems Studies. Как неоднократно подчеркивал Себеок, в частности в его вышедшей в 2001 году книге Global Semiotics, эстонские связи играют существенную роль в развитии семиотики.

\section{Modelleerimine, dialoog, globaalsus: biosemiootika ja enesesemiootika. 1. Semioos, modelleerimine, dialogism}

Esitatakse kriitiline ülevaade olukorrast semiootikas, pöörates erilist tähelepanu teoreetilistele probleemidele, mis koonduvad kultuuri ja looduse suhete ümber. Teiste sõnadega, me paigutame fookuse semiosfääri 
(J. Lotman) ja biosfääri (V. Vernadski) mõistete suhtele, arvestades erinevaid lähenemisi sellele küsimusele ja pakkudes välja oma vaatekoha. Oluline allikas tänapäeva semiootikast ülevaate saamisel on käsiraamat Semiotik/Semiotics, mille alapealkirjaks ei ole mitte juhuslikult Looduse ja kultuuri märgilis-teoreetiliste aluste käsiraamat. Selles käsiraamatus on oluline roll Thomas A. Sebeokil ja tema arusaamal semiootikast kui "globaalsest semiootikast". Üks kesksetest mõistetest Sebeoki globaalsemiootikas on modelleerimine, mis läbib nii loodust kui kultuuri. Modelleerimise mõiste ühendab kaks semioosi - loodusliku ja kultuurilise - ning viib mõistete "semiosfäär" ja "biosfäär" seose originaalse määratluseni. See problemaatika vastab ka semiootilistele uuringutele tänapäeva Tartus, mis leiab väljendust ajakirjas Sign Systems Studies. Nagu Sebeok oma kirjutistes rõhutas, sealhulgas 2001. aastal ilmunud raamatus Global Semiotics, on eesti-sidemed tähtsad semiootika arengu jaoks. 